\title{
Evaluation of Eleven Reference Evapotranspiration Models in Semiarid Conditions
}

\author{
Koffi Djaman ${ }^{*}$, Komlan Koudahe², Christopher Oluwakunmi Akinbile³, Suat Irmak ${ }^{4}$ \\ ${ }^{1}$ Department of Plant and Environmental Sciences, New Mexico State University, Agricultural Science Center at Farmington, \\ Farmington, USA \\ ${ }^{2}$ ADA Consulting Africa, Lome, Togo \\ ${ }^{3}$ Department of Agricultural \& Environmental Engineering, Federal University of Technology, Akure, Nigeria \\ ${ }^{4}$ Department of Biological Systems Engineering, University of Nebraska-Lincoln, Lincoln, USA \\ Email: *kdjaman@nmsu.edu
}

How to cite this paper: Djaman, K., Koudahe, K., Akinbile, C.O. and Irmak, S. (2017) Evaluation of Eleven Reference Evapotranspiration Models in Semiarid Conditions. Journal of Water Resource and Protection, 9, 1469-1490.

https://doi.org/10.4236/jwarp.2017.912094

Received: September 5, 2017

Accepted: November 26, 2017

Published: November 29, 2017

Copyright (c) 2017 by author(s) and Scientific Research Publishing Inc. This work is licensed under the Creative Commons Attribution International License (CC BY 4.0).

http://creativecommons.org/licenses/by/4.0/

\section{Open Access}

\begin{abstract}
The objectives of this study were to evaluate the performance of the FAO Penman Monteith reference evapotranspiration model under limited data and some mine temperature methods of reference evapotranspiration (ETo) under the semiarid and arid conditions in Mali. The results showed that under limited data conditions, the FAO-PM equation achieved accurate estimation of daily ETo when solar radiation, relative humidity, and wind speed are lacking individually with root mean squared errors (RMSE) averaging $0.52,0.56$ and $0.62 \mathrm{~mm} /$ day, respectively. Much more accurate ETo was estimated under relative humidity and wind speed missing data conditions with RMSE varying from 0.20 to $0.58 \mathrm{~mm} /$ day and average RE, MBE and MAE of $6.7 \%,-0.25$ $\mathrm{mm} /$ day and $0.30 \mathrm{~mm} /$ day. The Jensen-Haise equation systematically overestimated ETo while the Hansen, Christiansen, and Irmak, and the two Tabari's equations underestimated ETo at all weather stations. The Abtew equation showed the best performance among the selected ETo equations.
\end{abstract}

\section{Keywords}

Reference Evapotranspiration, Semiarid and Arid Climate, Mali

\section{Introduction}

Mean annual rainfall across the West African Sahel, varies from $100 \mathrm{~mm}$ to 600 $\mathrm{mm}$ covering 1 to 6 months with the decreasing trends from the southern limit to the northern limit [1]. The extremely high air temperature and the low rela- 
tive humidity increase the Evapotranspiration demand. Evapotranspiration is the main source of water losses and one of the important parameters under the hydrological, agricultural and environmental studies [2]. Under the Sahelo-Saharan climate conditions, water resource is one of the most factors limiting food production where insufficient and erratic rainfall limits rainfed agriculture in high risk production systems in terms of water stress. The Sahel is characterized by semi-arid climate under which effective water management is, therefore, critical. Accurate crop evapotranspiration estimation is critical for the water resources management under agricultural, hydrological and environmental processes. Management of water resources in the limited available water resources environment like the west African Sahel merit primordial attention for resource sustainability and improving water use efficiency [3] [4] [5]. Crop evapotranspiration is mostly estimated by the indirect method combining crop reference evapotranspiration (ETo) with crop coefficients [6] beside the direct measurement though lysimeters [7] [8]. Different methods for estimating ETo have been developed for different parts of the globe using climatic variables such as temperature, radiation, and combined variables [9]-[14]. While most of developed ETo equations have relative accuracy and adaptability to the local environment different from where they were developed, the Penman-Monteith ETo equation was demonstrated and shown to be the most accurate and adapted to all climatic conditions [12] [15]-[20]. The applicability of the Penman-Monteith ETo equation is constrained by the number and the non-availability of the full climatic dataset (temperature, relative humidity, solar radiation, and wind speed) mostly the developing countries like the sub-Saharan African countries. Scientists have to evaluate the adaptability of simple ETo equations to the local climatic conditions. One of the Valiantzas ETo equations was shown suitable ETo estimation across Burkina Faso [4] [21], Tanzania, Kenya and Uganda [20] [22]. Djaman et al. [3] reported the Trabert, Mahringer, Penman 1948, Albrecht, and two of Valiantzas' equations to perform well under the semiarid condition in Senegal River Delta and their calibration to the local climatic condition had improved daily ETo [5]. Tabari et al. [23] reported suitability of very few ETo equation to the Iranian environment while [24] indicated good performance of the calibrated forms of two of the Valiantzas equations to the Pilbara region of Western Australia.

While different equations have been tested and calibrated for different regions and sub-regions under different climatic conditions including in Canada [25], in Iran [26] [27] [28], in China [29], in Poland [30], in Florida (USA) [31], in Southeast Australia [32], and in Senegal [3], limited studies were conducted on the adaptability of reference evapotranspiration equation to the African SaheloSaharan region. Therefore, it is critical to assess the adaptability of ETo models and improve them through proper calibration to the local climate conditions. Thus, the objectives of this study were to: 1) evaluate the FAO-PM ETo equation under limited data condition, 2) evaluate nine temperature reference evapo- 
transpiration equations with comparison to the FAO-PM method, and 3) calibrate and validate the Abtew ETo equation [33] under the Malian semiarid and arid climate conditions.

\section{Materials and Methods}

\subsection{Data and Study Area}

Climatic data were collected at eleven weather stations across Mali (West Africa) for the period of 1990-2012. Maximum temperature (Tmax), minimum temperature (Tmin), maximum relative humidity (RHmax), minimum relative humidity (RHmin), wind speed ( $u 2)$, and solar radiation $(R s)$ data were collected from Bougouni, Hombori, Koutiala, Mopti, Nara, San, Segou, Senou, Sikasso, and Tessalit (Table 1). Mali has three climatic zones: the Sudanian zone with 700 to $1000 \mathrm{~mm}$ of annual precipitation, the Sahelian zone which receives 200 to 400 $\mathrm{mm}$ of precipitation, and the Saharan zone with little or no rain. Mali is among the hottest countries in the world. Most of Mali receives negligible rainfall and droughts are very frequent. The rainy season covers generally late June to early December in the southern area. The vast northern desert part of Mali has a hot desert climate with long, extremely hot summers and scarce rainfall which decreases northwards. The central area has a hot semi-arid climate with very high temperatures year-round, a long, intense dry season and a brief, irregular rainy season.

\subsection{Reference Evapotranspiration Equations}

- Penman-Monteith equation (FAO-PM)

Daily grass reference evapotranspiration (ETo-Ref) was calculated using the Penman-Monteith (FAO-PM) equation [12]. The Penman-Monteith reference evapotranspiration equation for grass surface is:

Table 1. Geographic coordinates and the climatic zones of the eleven weather stations.

\begin{tabular}{ccccc}
\hline $\begin{array}{c}\text { Weather } \\
\text { Stations }\end{array}$ & $\begin{array}{c}\text { Latitude } \\
\text { (Degree North) }\end{array}$ & $\begin{array}{c}\text { Longitude } \\
\text { (Degree East) }\end{array}$ & $\begin{array}{c}\text { Altitude } \\
(\mathrm{m})\end{array}$ & Climatic zones \\
\hline Bougouni & 11.42 & -7.5 & 344 & \\
Senou & 12.53 & -7.95 & 375 & Soudanian Zone \\
Sikasso & 11.35 & -5.68 & 284 & \\
Koutiala & 12.38 & -5.47 & 367 & \\
Mopti & 14.52 & -4.1 & 272 & Salelian Zone \\
Nara & 15.17 & -7.28 & 265 & \\
Niono & 14.23 & -5.98 & 277 & \\
San & 13.33 & -4.83 & 284 & Sahara Zone \\
Segou & 13.4 & -6.15 & 289 & \\
\hline Hombori & 15.33 & -1.68 & 288 & \\
Tessalit & 20.2 & -0.98 & 491 & \\
\hline
\end{tabular}




$$
\text { ETo }=\frac{0.408 \Delta(R n-G)+(\gamma C n u 2 /(T+273))(e s-e a)}{\Delta+\gamma(1+C d u 2)}
$$

where all variables are defined as described in [22]. All parameters necessary for computing ETo were computed according to the procedure developed in FAO-56 by [12].

The FAO-PM ETo model was evaluated under limited climatic data conditions for its performance and suitability under similar conditions as it is almost the case in most of the developing countries where climatic data record is not consistent and with missing variables [3] [34] [35] [36] [37].

Thus, the following acronyms were used for ETo estimated using: 1) FAO-56 Penman Monteith equation with full data set is referred as FAO-PM ETo, 2) ETo-Rs when Rs is missing, 3) ETo-Tmin when RH is missing, 4) ETo-um when $\mathrm{u} 2$ is missing, 5) ETo-RsTmin when $R s$ and $R H$ are missing, 6) ETo-Rsum when $R s$ and $\mathrm{u} 2$ are missing, 7) ETo-umTmin when $\mathrm{u} 2$ and $\mathrm{RH}$ are missing, 8) ETo-RsumTmin when Rs, $\mathrm{RH}$ and $\mathrm{u} 2$ are missing.

- Jensen and Haise [6] method:

$$
\text { ETo }=(0.025 T \text { mean }+0.08) \frac{R s}{\lambda}
$$

- Hansen [38] method:

$$
\mathrm{ETo}=0.7 \frac{\Delta}{\Delta+\gamma} \frac{R a}{\lambda}
$$

- Abtew [33] method 1: Abtew

$$
\mathrm{ETo}=\frac{\operatorname{Tmax}}{K} \frac{R s}{\lambda}
$$

- Calibrated Christiansen [33] method:

$$
\mathrm{ETo}=0.53 \frac{R s}{\lambda}
$$

- Droogers and Allen [39] method: Dr-Al

$$
\mathrm{ETo}=0.003(\text { Tmean }+20)(\text { Tmax }- \text { Tmin })^{0.4} R a
$$

- Hargreaves and Allen [40] method: Harg

$$
\text { ETo }=(0.0135 \text { Tmean }+0.2403) \frac{R s}{\lambda}
$$

- Irmak [41] method:

$$
\mathrm{ETo}=-0.611+0.149 R s+0.079 \text { Tmean }
$$

- Tabari [23] method 1: Tabari 1

$$
\text { ETo }=-0.642+0.174 R s+0.0353 \text { Tmean }
$$

- Tabari [23] method 2: Tabari 2

$$
\text { ETo }=-0.478+0.156 R s-0.0112 \text { Tmax }+0.0733 \text { Tmin }
$$

where, Tmax, Tmin and Tmean are daily maximum, minimum and mean air 
temperature $\left({ }^{\circ} \mathrm{C}\right)$, respectively; $R s$ is solar radiation, $R a$ is extraterrestrial radiation $\left(\mathrm{MJm}^{-2} \cdot \mathrm{day}^{-1}\right), K$ is dimensionless coefficient to be determined for each location.

- Multi-model ensemble (MME)

Simple multi-model ensemble (MME) was constructed by combining all the nine the individual ensemble of ETo models with equal weights [42] [43]. Multi-model ensemble outperforms single models in their skill due to error cancellation and the nonlinearity of the skill metrics applied. Hagedorn et al. [43] reported that it is not usually possible to identify a "best" or a "poorest" model from a set of models, as their individual strengths and flaws typically vary with location and initialization time. In this method, MME forecasts are generated by simply pooling together the participating simple models, with all ensemble members having equal weight [43]. We assume that this procedure might solve the quantification of all aspects of all simple models uncertainties with increasing model performance as demonstrated by [44] [45] [46] [47].

\subsection{Calibration of the Abtew ETo Equation}

To calibrate the ETo equations, a linear regression relationship between daily PM-ETo and daily ETo estimates by the Abtew equation was determined and the calibration coefficients were then obtained by multiplying the slope of a regression line between ETo estimate by an ETo equation and the PM-ETo by its inverse to bring the slope of the regression line to the unity. And, the opposite value of the intercept was added to the new regression relationship to minimize the new intercept (as close to zero as possible). The dependent variable was ETo estimated by the PM-ETo and the independent variable was the ETo estimations by the Abtew equation. Therefore, the calibration processes tend to have a new regression relationship with a slope as unity and intercept as zero. The Abtew ETo equation was calibrated and validated using all eleven weather stations. The data from 1990 to 2003 were used for the equation calibration and data from 2004 to 2012 were used for the validation. This partitioning is due to the need of more data for training the equation as suggested by [28] [48].

\subsection{Evaluation Criteria}

Simple linear regression was used for models comparison with reference to the FAO-PM. Root mean squared error (RMSE), relative error (RE), mean bias error $(\mathrm{MBE})$, and the absolute mean error (AME) were also used for model evaluation and calculated as follow:

$$
\begin{gathered}
\text { RMSE }=\sqrt{\sum_{i=0}^{n} \frac{(E i-O i)^{2}}{n}} \\
\mathrm{RE}=\frac{\text { RMSE }}{\text { ETomean }} \times 100 \\
\mathrm{MBE}=n^{-1} \sum_{1}^{n}(E i-O i)
\end{gathered}
$$




$$
\mathrm{AME}=n^{-1} \sum_{1}^{n}|\mathrm{Ei}-\mathrm{Oi}|
$$

where, $E i$ is the estimated ETo with FAO-PM under limited data and the temperature ETo models; and $\mathrm{Oi}$ is ETo estimated with FAO-PM model with full dataset, at the ith data point and $n$ is the total number of data points.

\section{Results and Discussion}

\subsection{Performance of the FA0-PM Equation under Limited Data}

The FAO-PM equation performed relatively well under limited data conditions in the semiarid and arid conditions in Mali. Under solar radiation missing, the FAO-PM (ETo-Rs) overall underestimated the daily ETo with the best performance at Nara in the Sahelian zone and Tessalit in the Sahara zone. The regression slope between FAO-PM ETo and ETo-Rs was very high and varied from 0.934 to 0.999 and the $\mathrm{R}^{2}$ ranged from 0.68 to 0.96 (Table 2). ETo underestimation

Table 2. Comparison between FAO-PM ETo computed from full Data set and FAO-PM ETo computed with limited data when $\mathrm{Rs}, \mathrm{RH}$, and $\mathrm{u} 2$ are missing.

\begin{tabular}{|c|c|c|c|c|c|c|c|c|}
\hline Indices & Locations & ETo-Rs & ETo-Tmin & ETo-um & ETO-RsTmin & ETo-Rsum & ETo-umTmin & ETo-RsumTmin \\
\hline \multirow{12}{*}{$\begin{array}{l}\text { Regression } \\
\text { slope }\end{array}$} & Bougouni & 0.941 & 0.944 & 1.133 & 0.876 & 1.077 & 1.001 & 0.937 \\
\hline & Hombori & 0.936 & 0.914 & 1.143 & 0.816 & 1.081 & 0.957 & 0.863 \\
\hline & Koutiala & 0.958 & 0.929 & 1.123 & 0.884 & 1.083 & 0.982 & 0.939 \\
\hline & Mopti & 0.971 & 0.905 & 1.084 & 0.877 & 1.056 & 0.942 & 0.914 \\
\hline & Nara & 0.996 & 0.898 & 1.072 & 0.905 & 1.069 & 0.930 & 0.938 \\
\hline & Niono & 0.962 & 0.904 & 1.086 & 0.861 & 1.049 & 0.939 & 0.897 \\
\hline & San & 0.964 & 0.920 & 1.104 & 0.883 & 1.068 & 0.967 & 0.931 \\
\hline & Segou & 0.970 & 0.901 & 1.087 & 0.869 & 1.058 & 0.937 & 0.906 \\
\hline & Senou & 0.956 & 0.929 & 1.127 & 0.875 & 1.084 & 0.980 & 0.929 \\
\hline & Sikasso & 0.950 & 0.934 & 1.112 & 0.878 & 1.064 & 0.9841 & 0.930 \\
\hline & Tessalit & 0.999 & 0.901 & 1.078 & 0.900 & 1.077 & 0.934 & 0.933 \\
\hline & Average & 0.964 & 0.916 & 1.104 & 0.875 & 1.070 & 0.957 & 0.920 \\
\hline \multirow{12}{*}{$\mathrm{R}^{2}$} & Bougouni & 0.70 & 0.95 & 0.92 & 0.64 & 0.67 & 0.96 & 0.65 \\
\hline & Hombori & 0.68 & 0.89 & 0.87 & 0.76 & 0.49 & 0.92 & 0.73 \\
\hline & Koutiala & 0.74 & 0.93 & 0.94 & 0.69 & 0.70 & 0.94 & 0.68 \\
\hline & Mopti & 0.78 & 0.91 & 0.97 & 0.77 & 0.74 & 0.93 & 0.75 \\
\hline & Nara & 0.85 & 0.91 & 0.99 & 0.81 & 0.82 & 0.92 & 0.80 \\
\hline & Niono & 0.79 & 0.91 & 0.98 & 0.76 & 0.75 & 0.92 & 0.75 \\
\hline & San & 0.75 & 0.92 & 0.96 & 0.73 & 0.70 & 0.94 & 0.71 \\
\hline & Segou & 0.80 & 0.90 & 0.98 & 0.76 & 0.77 & 0.92 & 0.75 \\
\hline & Senou & 0.76 & 0.93 & 0.94 & 0.68 & 0.73 & 0.94 & 0.68 \\
\hline & Sikasso & 0.74 & 0.94 & 0.94 & 0.66 & 0.72 & 0.95 & 0.67 \\
\hline & Tessalit & 0.96 & 0.94 & 1.00 & 0.92 & 0.96 & 0.95 & 0.91 \\
\hline & Average & 0.78 & 0.92 & 0.95 & 0.74 & 0.73 & 0.94 & 0.73 \\
\hline
\end{tabular}


was revealed through the $\mathrm{MBE}$ that average $-0.18 \mathrm{~mm}$ /day and the MAE average of $0.38 \mathrm{~mm} /$ day (Table 3 ). Under missing $\mathrm{RH}$ conditions and when the actual vapor pressure is estimated with Tmin, ETo-Tmin basically underestimated daily ETo at lower rate of daily evapotranspiration less than $6 \mathrm{~mm} /$ day (Figure 1). The largest underestimation was observes at Nara and Tessalit when the MBE was -0.66 and $-0.69 \mathrm{~mm} / \mathrm{day}$, and the MAE was 0.66 and $0.69 \mathrm{~mm} / \mathrm{day}$, respectively (Table 3 ). The least RE was observed at Bougouni (7.1\%), the largest RE (12\%) was observed at Nara and the average RE was $10 \%$ that showed the applicability of the method in the case of missing $\mathrm{RH}$ data. Large overestimation of daily ETo between $7 \%$ and 14\% that averaged 10\% (Figure 1) was obtained when the global average wind speed of $2 \mathrm{~m} / \mathrm{s}$ was used (Table 2) with RMSE that varied from 0.51 and $0.85 \mathrm{~mm} /$ day, $\mathrm{RE}$ from $7.7 \%$ to $15.5 \%$, and MBE from 0.44 and $0.79 \mathrm{~mm} /$ day (Table 3 ). However, very high $\mathrm{R}^{2}$ varying from 0.87 and 1.0 was obtained between FAO-PM ETo with full data set and ETo-um. When Rs and $\mathrm{RH}$ data are missing, ETo-RsTmin underestimated the daily ETo with RMSE ranging from 0.78 to $1.08 \mathrm{~mm} /$ day, $\mathrm{MBE}$ from -0.58 to $-1.01 \mathrm{~mm} /$ day, high RE that varied from $12.5 \%$ to $19.6 \%$ (Table 3 ). ETo overestimation average of $7 \%$ was observed in the case of missing Rs and wind speed with no geographical specificity. In this case, RE was as high as $17.6 \%$ at Bougouni and average 13.9\% (Table 3). Under missing wind speed and $\mathrm{RH}$ data, ETo-umTmin had relatively low RMSE that varied from 0.20 to $0.56 \mathrm{~mm} /$ day and low RE always less than $10 \%$ and averaging $6.7 \%$, MBE average of $-0.25 \mathrm{~mm} / \mathrm{day}$, and $\mathrm{MAE}$ average of $0.30 \mathrm{~mm} /$ day. The lowest RE was obtained at Bougouni (4\%) when the null MBE was observed and the lowest MAE of $0.14 \mathrm{~mm} /$ day. When the RS, $\mathrm{RH}$, and $\mathrm{u} 2$ are missing the FAO-PM has the poorest performance at all locations across Mali with large RMSE varying from 0.64 to $0.84 \mathrm{~mm} /$ day, high RE averaging $13 \%$, and MBE varying from -0.75 to $-0.29 \mathrm{~mm} /$ day, and MAE averaging $0.59 \mathrm{~mm} /$ day (Table 3 ). Therefore it is not recommend using the FAO-PM equation under this condition across the semiarid and arid conditions across Mali.

The results of this study are in agreement with previous research under similar climatic conditions. Similar results were reported by [4] during their study across Burkina Faso. Rojas and Thepadia [37] reported better results of the FAO-PM ETo equation when using wind speed data from a neighboring site in northeast Louisiana compared to the adoption of the global average wind speed of $2 \mathrm{~m} / \mathrm{s}$ with a mean ratio of 0.98 and MAE of $0.56 \mathrm{~mm} /$ day. Trajkovic and Kolakovic [8] reported that the discrepancies between ETo under full data set and ETo under limited data set increased with increasing number of estimates weather parameters. Popova et al. [49] reported that the ETo estimation by FAO-PM under limited data provided accurate estimates of ETo with small standard errors of estimates. In contrast, [50] showed small differences in terms of MBE varying -0.22 to $0.25 \mathrm{~mm} /$ day and small RMSE varying $0.06-0.50$ $\mathrm{mm}$ /day when they comparing ETo-RS and FAO-PM ETo with full data set in Korea. The results are close enough to the results of [51] who indicated that under missing Rs data, temperatures could be used to derive Rs for ETo estimation 
Table 3. Statistical indices for the evaluation of FAO-PM ETo computed with limited data when Rs, RH, and u2 are missing.

\begin{tabular}{|c|c|c|c|c|c|c|c|c|}
\hline Indices & Locations & ETo-Rs & ETo-Tmin & ETo-um & ETO-RsTmin & ETo-Rsum & ETo-umTmin & ETo-RsumTmin \\
\hline \multirow{12}{*}{$\begin{array}{c}\text { RMSE } \\
(\mathrm{mm} / \text { day) }\end{array}$} & Bougouni & 0.60 & 0.34 & 0.75 & 0.80 & 0.85 & 0.20 & 0.67 \\
\hline & Hombori & 0.53 & 0.56 & 0.85 & 1.08 & 0.77 & 0.35 & 0.84 \\
\hline & Koutiala & 0.55 & 0.44 & 0.71 & 0.79 & 0.84 & 0.25 & 0.67 \\
\hline & Mopti & 0.54 & 0.62 & 0.51 & 0.87 & 0.72 & 0.44 & 0.75 \\
\hline & Nara & 0.47 & 0.74 & 0.47 & 0.80 & 0.71 & 0.56 & 0.70 \\
\hline & Niono & 0.55 & 0.65 & 0.53 & 0.96 & 0.70 & 0.47 & 0.83 \\
\hline & San & 0.57 & 0.52 & 0.62 & 0.83 & 0.81 & 0.31 & 0.70 \\
\hline & Segou & 0.53 & 0.65 & 0.53 & 0.91 & 0.71 & 0.47 & 0.78 \\
\hline & Senou & 0.57 & 0.40 & 0.64 & 0.80 & 0.77 & 0.22 & 0.67 \\
\hline & Sikasso & 0.55 & 0.45 & 0.73 & 0.84 & 0.82 & 0.27 & 0.70 \\
\hline & Tessalit & 0.28 & 0.75 & 0.51 & 0.78 & 0.59 & 0.58 & 0.64 \\
\hline & Average & 0.52 & 0.56 & 0.62 & 0.86 & 0.75 & 0.38 & 0.72 \\
\hline \multirow{11}{*}{ RE (\%) } & Bougouni & 12.4 & 7.1 & 15.5 & 16.5 & 17.6 & 4.1 & 13.9 \\
\hline & Hombori & 9.6 & 10.2 & 15.5 & 19.6 & 13.9 & 6.4 & 15.3 \\
\hline & Koutiala & 10.8 & 8.7 & 13.8 & 15.5 & 16.3 & 5.0 & 13.0 \\
\hline & Mopti & 9.6 & 11.1 & 9.2 & 15.6 & 12.9 & 7.8 & 13.4 \\
\hline & Nara & 7.6 & 12.0 & 7.7 & 13.1 & 11.5 & 9.2 & 11.5 \\
\hline & Niono & 9.6 & 11.3 & 9.3 & 16.8 & 12.2 & 8.3 & 14.5 \\
\hline & San & 10.5 & 9.6 & 11.5 & 15.3 & 14.9 & 5.8 & 13.0 \\
\hline & Segou & 9.5 & 11.6 & 9.5 & 16.2 & 12.7 & 8.4 & 13.9 \\
\hline & Senou & 11.5 & 8.1 & 12.9 & 16.2 & 15.6 & 4.5 & 13.6 \\
\hline & Sikasso & 10.7 & 8.8 & 14.2 & 16.3 & 16.0 & 5.3 & 13.5 \\
\hline & Tessalit & 4.4 & 11.9 & 8.1 & 12.5 & 9.4 & 9.2 & 10.2 \\
\hline \multirow{13}{*}{$\begin{array}{c}\mathrm{MBE} \\
(\mathrm{mm} / \text { day })\end{array}$} & Average & 9.7 & 10.0 & 11.6 & 15.8 & 13.9 & 6.7 & 13.3 \\
\hline & Bougouni & -0.27 & -0.27 & 0.62 & -0.58 & 0.36 & 0.00 & -0.29 \\
\hline & Hombori & -0.33 & -0.49 & 0.79 & -1.01 & 0.47 & -0.26 & -0.75 \\
\hline & Koutiala & -0.20 & -0.36 & 0.61 & -0.58 & 0.41 & -0.10 & -0.31 \\
\hline & Mopti & -0.16 & -0.54 & 0.46 & -0.70 & 0.31 & -0.34 & -0.49 \\
\hline & Nara & -0.02 & -0.66 & 0.44 & -0.61 & 0.42 & -0.46 & -0.41 \\
\hline & Niono & -0.21 & -0.57 & 0.48 & -0.80 & 0.28 & -0.37 & -0.60 \\
\hline & San & -0.19 & -0.44 & 0.55 & -0.63 & 0.36 & -0.19 & -0.38 \\
\hline & Segou & -0.17 & -0.56 & 0.47 & -0.74 & 0.31 & -0.36 & -0.53 \\
\hline & Senou & -0.24 & -0.31 & 0.52 & -0.58 & 0.30 & -0.08 & -0.33 \\
\hline & Sikasso & -0.21 & -0.37 & 0.63 & -0.62 & 0.42 & -0.11 & -0.35 \\
\hline & Tessalit & 0.00 & -0.69 & 0.50 & -0.67 & 0.50 & -0.48 & -0.46 \\
\hline & Average & -0.18 & -0.48 & 0.55 & -0.68 & 0.38 & -0.25 & -0.45 \\
\hline
\end{tabular}




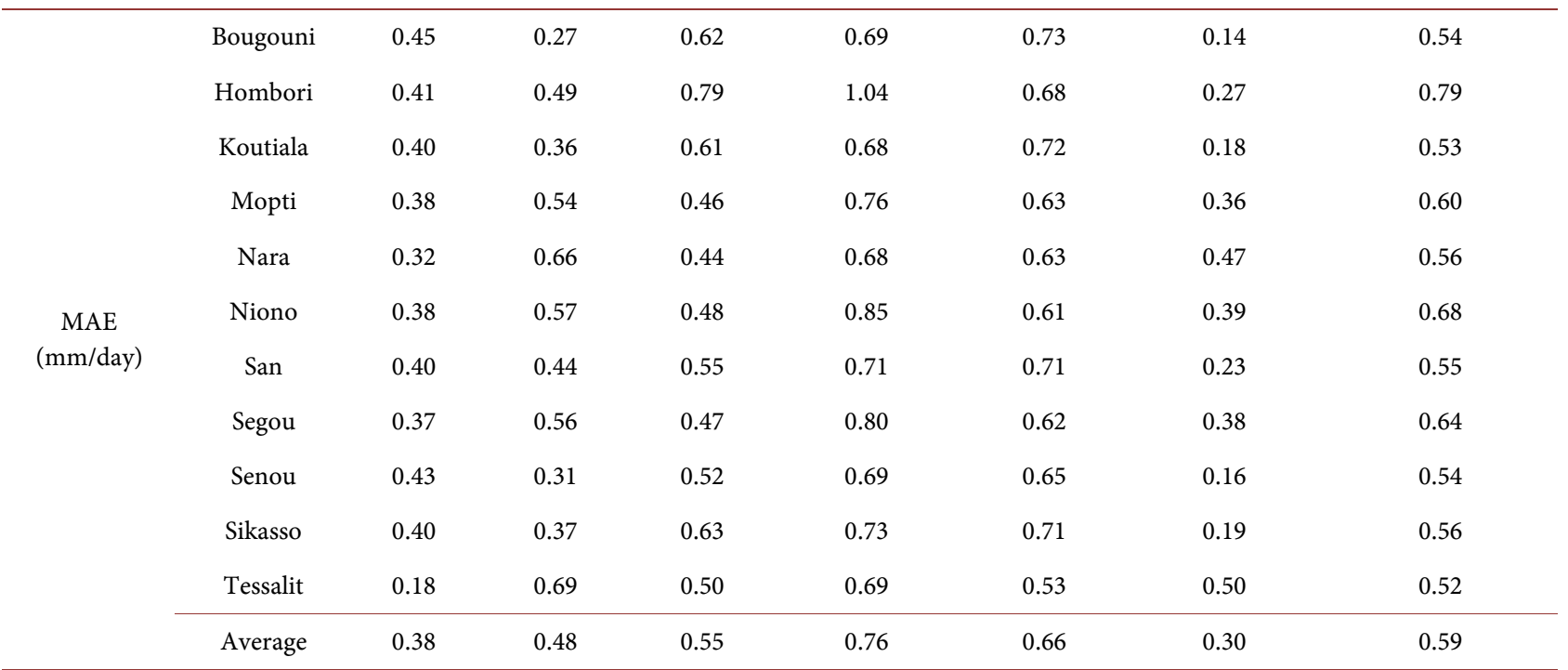
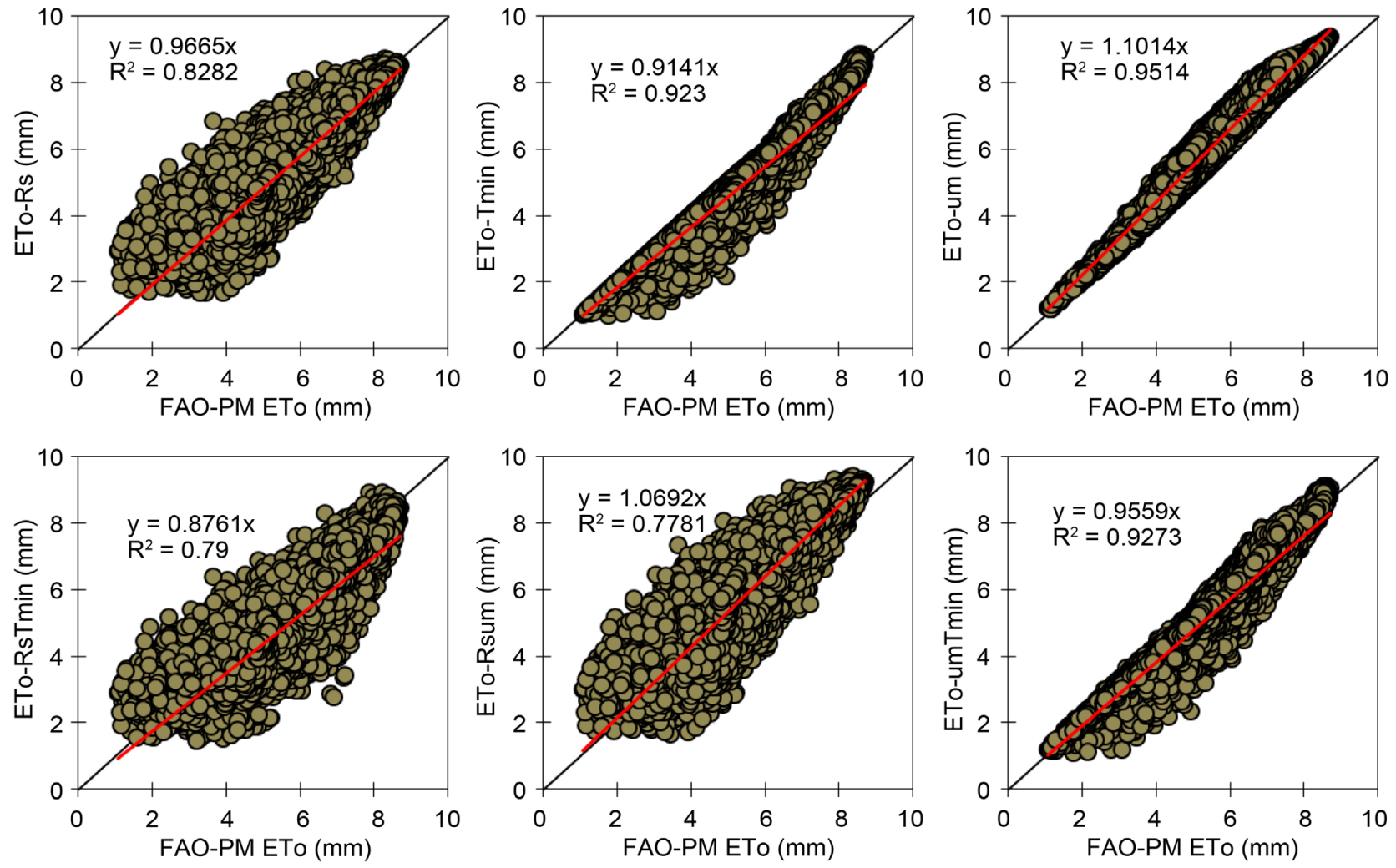

Figure 1. Relationship between the FAO-PM daily ETo computed with full data and the daily ETo by the FAO-PM under limited data conditions.

in the Mediterranean environment. They reported very high $\mathrm{R}^{2} \geq 0.98$ using this method and RMSE varying from 0.42 to $0.71 \mathrm{~mm} /$ day. Wang et al. [52] indicated accurate estimates of ETo when RH is missing in Malawi. Jabloun and Sahli [34] also reported similar results under semiarid conditions in Tunisia. These results corroborated the finding of [4] for their study under semiarid climate in Burkina 
Faso. In Southern Ontario, Canada, ETo-Tmin overestimated ETo up to $12 \%$ as reported by [35]. Kwon and Choi [50] reported large RMSE of $0.6-0.73$ $\mathrm{mm}$ /day under missing $\mathrm{RH}$ data in Korea. Under missing wind speed data, [34] reported close to unity regression slopes and very high $\mathrm{R}^{2}(>0.96)$ in Tunisia. [4] [8] [34] [37] reported that the use of global wing speed average of $2 \mathrm{~m} / \mathrm{s}$ should be replaced by the local average wind speed data that provided better estimates of ETo. Under missing $\mathrm{RH}$ and $\mathrm{u} 2$, the results of this study are in agreement with [35] who reported that under missing $\mathrm{RH}$ and $\mathrm{u} 2$, FAO-PM method showed good estimation of daily ETo in the Southern Ontario, with RMSE < $0.53 \mathrm{~mm} /$ day. However, when three climatic variables were mission, the results showed the poorest performance of the FAO-PM model as reported by [34] [50] [53].

\subsection{Evaluation of the Selected ETo Equations}

The tested ETo equations had different performance at the eleven weather stations in Mali. The Jensen-Haise equation systematically overestimated ETo at all sites (Table 3) with RMSE ranging from 1.6 to $2.0 \mathrm{~mm} /$ day, the RE within the range of $26.3 \%$ to $37.6 \%$ averaging $32.1 \%$, and average AME of $1.55 \mathrm{~mm} /$ day (Table 5). The highest overestimation was recorded at Bougouni, Senou and Sikasso, all under the Sudanian climate. The Hansen, Christiansen, and Irmak ETo equations had similar performance and slightly underestimated ETo (Table 4). The regression slope varied from 0.79 to 0.94 , from 0.76 to 0.92 , and from 0.79 to 0.95 for the Hansen, Christiansen, and Imak equations, respectively, and the RMSE varied from 0.52 to $1.44 \mathrm{~mm} /$ day, from 0.63 to $1.66 \mathrm{~mm} / \mathrm{day}$, and from 0.45 to $1.43 \mathrm{~mm} /$ day for the respective ETo equations (Table 5). The relative error averaged $17 \%, 19 \%$, and $15 \%$ under the Hansen, Christiansen, and Imak equations while the MBE averaged $-0.75,-0.85$, and $-0.69 \mathrm{~mm} /$ day for the respective equations. These three ETo equations had the best performance at Bougouni under the Sudanian climate and the worst performance at Nara under the Sahelian climate.

The Abtew dimensionless coefficient $\mathrm{K}$ varied with locations and was 58.67, 57.75, and 57.55 at Bougouni, Senou, Sikasso, respectively, in the Soudanian zone; 57.54, 55.58, 55.08, 55.96, 56.94, 55.37 at Koutiala, Mopti, Nara, Niono, San, and Segou, respectively, for the Sahelian Zone; and 57.97 and 56.31 at Hombori and Tessalit, respectively, for the Sahara zone. Overall, there was not particular correlation between $\mathrm{K}$ and the geographical coordinates of the weather stations. However, good correlation between $\mathrm{K}$ values and the latitudes of the weather stations was found only for the Sahelian zone $(\mathrm{K}=30.864 \times$ Altitude 1438.5 with $\mathrm{R}^{2}=0.63$ ) and this relation could be introduced into the original Abtew equation for regionalization under the Sahelian conditions. The Abtew equation showed the best performance among the ETo equations, slightly better than the [39] (Dr-Al) and [40] (Harg.) equations (Table 4 and Table 5). The regression slopes varied from 0.98 to 1.03 , from 0.91 to 0.99 , and from 0.90 to 1.07 for the Abtew, Dr- $\mathrm{Al}$ and Harg equations with average $\mathrm{R}^{2}$ of $0.86,0.74$ and 0.79 , and 
Table 4. Comparison between FAO-PM ETo computed from full data set and ETo computed with selected models.

\begin{tabular}{|c|c|c|c|c|c|c|c|c|c|c|c|}
\hline Indexes & Locations & Jensen-Haise & Hansen & Abtew & Christiansen & Dr-Al & Harg & Irmak & Tabari 1 & Tabari 2 & MME \\
\hline \multirow{11}{*}{$\begin{array}{l}\text { Regression } \\
\text { slope }\end{array}$} & Bougouni & 1.354 & 0.936 & 0.994 & 0.919 & 0.981 & 1.065 & 0.945 & 0.803 & 0.815 & 0.979 \\
\hline & Hombori & 1.336 & 0.915 & 0.993 & 0.896 & 0.906 & 1.045 & 0.903 & 0.779 & 0.785 & 0.951 \\
\hline & Koutiala & 1.313 & 0.896 & 0.997 & 0.873 & 0.979 & 0.896 & 0.906 & 0.766 & 0.774 & 0.947 \\
\hline & Mopti & 1.245 & 0.831 & 0.989 & 0.820 & 0.946 & 0.970 & 0.847 & 0.719 & 0.717 & 0.899 \\
\hline & Nara & 1.196 & 0.790 & 0.985 & 0.761 & 0.959 & 0.922 & 0.794 & 0.672 & 0.659 & 0.860 \\
\hline & Niono & 1.260 & 0.843 & 0.989 & 0.817 & 0.929 & 0.977 & 0.845 & 0.718 & 0.719 & 0.900 \\
\hline & San & 1.283 & 0.871 & 0.991 & 0.850 & 0.965 & 1.000 & 0.876 & 0.745 & 0.745 & 0.925 \\
\hline & Segou & 1.251 & 0.836 & 0.990 & 0.809 & 0.938 & 0.968 & 0.846 & 0.713 & 0.718 & 0.897 \\
\hline & Senou & 1.322 & 0.898 & 0.993 & 0.903 & 0.970 & 1.031 & 0.907 & 0.767 & 0.777 & 0.949 \\
\hline & Sikasso & 1.324 & 0.916 & 0.995 & 0.757 & 0.973 & 1.043 & 0.928 & 0.788 & 0.798 & 0.963 \\
\hline & Tessalit & 1.209 & 0.791 & 0.982 & 0.873 & 0.958 & 0.927 & 0.782 & 0.666 & 0.647 & 0.858 \\
\hline \multicolumn{2}{|c|}{ Average } & 1.28 & 0.87 & 0.99 & 0.84 & 0.95 & 0.99 & 0.87 & 0.74 & 0.74 & 0.92 \\
\hline \multirow{11}{*}{$\mathrm{R}^{2}$} & Bougouni & 0.89 & 0.79 & 0.91 & 0.66 & 0.64 & 0.86 & 0.72 & 0.74 & 0.52 & 0.90 \\
\hline & Hombori & 0.82 & 0.80 & 0.83 & 0.76 & 0.75 & 0.82 & 0.84 & 0.80 & 0.78 & 0.86 \\
\hline & Koutiala & 0.83 & 0.72 & 0.88 & 0.55 & 0.68 & 0.72 & 0.65 & 0.65 & 0.44 & 0.85 \\
\hline & Mopti & 0.76 & 0.70 & 0.83 & 0.55 & 0.77 & 0.75 & 0.68 & 0.65 & 0.50 & 0.82 \\
\hline & Nara & 0.73 & 0.69 & 0.80 & 0.57 & 0.82 & 0.74 & 0.73 & 0.66 & 0.55 & 0.81 \\
\hline & Niono & 0.79 & 0.72 & 0.84 & 0.57 & 0.77 & 0.78 & 0.72 & 0.67 & 0.56 & 0.84 \\
\hline & San & 0.78 & 0.70 & 0.86 & 0.55 & 0.73 & 0.77 & 0.65 & 0.64 & 0.45 & 0.83 \\
\hline & Segou & 0.77 & 0.65 & 0.84 & 0.46 & 0.75 & 0.75 & 0.60 & 0.58 & 0.40 & 0.79 \\
\hline & Senou & 0.86 & 0.75 & 0.88 & 0.59 & 0.67 & 0.84 & 0.69 & 0.69 & 0.52 & 0.87 \\
\hline & Sikasso & 0.86 & 0.74 & 0.90 & 0.73 & 0.65 & 0.82 & 0.62 & 0.67 & 0.39 & 0.86 \\
\hline & Tessalit & 0.83 & 0.88 & 0.85 & 0.58 & 0.92 & 0.88 & 0.95 & 0.87 & 0.90 & 0.92 \\
\hline \multicolumn{2}{|c|}{ Average } & 0.81 & 0.74 & 0.86 & 0.60 & 0.74 & 0.79 & 0.71 & 0.69 & 0.55 & 0.85 \\
\hline
\end{tabular}

MBE of $-0.05,-0.25$ and $-0.05 \mathrm{~mm} /$ day for the respective ETo equations. The Abtew equation obtained the least relative errors that averaged 9.83\% and AME of $0.41 \mathrm{~mm} /$ day. They showed better performance under the Sudanian and Sahelian semiarid climates. The Tabari 1 and Tabari 2 ETo equations did not show good performance under the Sudano-Sahelo semiarid and Saharan arid conditions in Mali. Both equations systematically underestimated daily ETo across the study area with RMSE that averaged 1.53 and $1.54 \mathrm{~mm} /$ day, MBE of -1.42 and $-1.41 \mathrm{~mm} /$ day, and AME of 1.42 and $1.42 \mathrm{~mm}$ /day, respectively. The Tabari ETo equations showed the best performance with the lowest RMSE of 1.04 and 1.01 $\mathrm{mm}$ /day and the lowest AME of 0.93 and $0.86 \mathrm{~mm} /$ day at Bougouni in the Sudanian semiarid climate zone (Table 5). It can be deducted that the Abtew ETo equation was revealed the best among the nine temperature ETo equations which obtained the best evaluation indices across the study area. Therefore, it 
Table 5. Statistical indices summary for the reference evapotranspiration equations evaluation.

\begin{tabular}{|c|c|c|c|c|c|c|c|c|c|c|c|}
\hline Indexes & Locations & Jensen-Haise & Hansen & Abtew & Christiansen & Dr-Al & Harg & Irmak & Tabari 1 & Tabari 2 & MME \\
\hline \multirow{11}{*}{$\begin{array}{c}\text { RMSE } \\
\text { (mm/day) }\end{array}$} & Bougouni & 1.82 & 0.52 & 0.37 & 0.63 & 0.59 & 0.52 & 0.45 & 1.04 & 1.01 & 0.31 \\
\hline & Hombori & 1.97 & 0.63 & 0.48 & 0.72 & 0.66 & 0.55 & 0.60 & 1.27 & 1.23 & 0.43 \\
\hline & Koutiala & 1.75 & 0.72 & 0.44 & 0.85 & 0.57 & 0.50 & 0.63 & 1.29 & 1.27 & 0.44 \\
\hline & Mopti & 1.65 & 1.05 & 0.60 & 1.17 & 0.61 & 0.65 & 0.97 & 1.66 & 1.69 & 0.72 \\
\hline & Nara & 1.61 & 1.44 & 0.77 & 1.61 & 0.61 & 0.88 & 1.36 & 2.10 & 2.20 & 1.02 \\
\hline & Niono & 1.74 & 1.06 & 0.60 & 1.21 & 0.67 & 0.62 & 0.99 & 1.70 & 1.71 & 0.72 \\
\hline & San & 1.74 & 0.88 & 0.51 & 1.00 & 0.58 & 0.57 & 0.80 & 1.47 & 1.49 & 0.57 \\
\hline & Segou & 1.65 & 1.09 & 0.57 & 1.26 & 0.65 & 0.63 & 0.99 & 1.71 & 1.69 & 0.74 \\
\hline & Senou & 1.79 & 0.71 & 0.44 & 0.86 & 0.60 & 0.49 & 0.62 & 1.28 & 1.25 & 0.43 \\
\hline & Sikasso & 1.71 & 0.61 & 0.37 & 0.71 & 0.58 & 0.49 & 0.54 & 1.13 & 1.12 & 0.38 \\
\hline & Tessalit & 1.77 & 1.42 & 0.86 & 1.66 & 0.55 & 0.81 & 1.43 & 2.18 & 2.29 & 1.01 \\
\hline \multicolumn{2}{|c|}{ Average } & 1.74 & 0.92 & 0.56 & 1.06 & 0.61 & 0.61 & 0.85 & 1.53 & 1.54 & 0.62 \\
\hline \multirow{11}{*}{ RE (\%) } & Bougouni & 37.60 & 10.74 & 7.66 & 13.04 & 12.16 & 10.78 & 9.28 & 21.43 & 20.87 & 6.31 \\
\hline & Hombori & 35.82 & 11.45 & 8.77 & 13.06 & 11.91 & 9.92 & 10.96 & 23.03 & 22.36 & 7.84 \\
\hline & Koutiala & 34.06 & 14.01 & 8.49 & 16.64 & 11.15 & 9.83 & 12.21 & 25.04 & 24.76 & 8.66 \\
\hline & Mopti & 29.48 & 18.85 & 10.72 & 21.03 & 10.94 & 11.66 & 17.35 & 29.66 & 30.27 & 12.94 \\
\hline & Nara & 26.29 & 23.54 & 12.48 & 26.31 & 9.89 & 14.30 & 22.13 & 34.30 & 35.85 & 16.56 \\
\hline & Niono & 30.38 & 18.49 & 10.49 & 21.20 & 11.80 & 10.83 & 17.27 & 29.70 & 29.83 & 12.63 \\
\hline & San & 32.18 & 16.27 & 9.46 & 18.56 & 10.81 & 10.61 & 14.79 & 27.18 & 27.69 & 10.65 \\
\hline & Segou & 29.33 & 19.46 & 10.16 & 22.35 & 11.50 & 11.30 & 17.58 & 30.35 & 30.17 & 13.18 \\
\hline & Senou & 34.78 & 13.74 & 8.64 & 16.66 & 11.69 & 9.61 & 12.05 & 24.98 & 24.33 & 8.43 \\
\hline & Sikasso & 34.78 & 12.41 & 7.57 & 14.48 & 11.81 & 10.04 & 10.98 & 23.01 & 22.72 & 7.65 \\
\hline & Tessalit & 28.29 & 22.73 & 13.70 & 26.49 & 8.81 & 12.93 & 22.80 & 34.80 & 36.61 & 16.19 \\
\hline \multicolumn{2}{|c|}{ Average } & 32.09 & 16.52 & 9.83 & 19.07 & 11.13 & 11.07 & 15.22 & 27.59 & 27.77 & 11.00 \\
\hline \multirow{11}{*}{$\begin{array}{c}\mathrm{MBE} \\
(\mathrm{mm} / \text { day })\end{array}$} & Bougouni & 1.69 & -0.30 & -0.07 & -0.36 & -0.06 & 0.31 & -0.21 & -0.93 & -0.85 & -0.09 \\
\hline & Hombori & 1.79 & -0.48 & -0.09 & -0.58 & -0.52 & 0.22 & -0.52 & -1.22 & -1.18 & -0.29 \\
\hline & Koutiala & 1.58 & -0.52 & -0.08 & -0.61 & -0.09 & 0.13 & -0.43 & -1.17 & -1.12 & -0.26 \\
\hline & Mopti & 1.31 & -0.88 & -0.13 & -0.97 & -0.30 & -0.19 & -0.82 & -1.55 & -1.55 & -0.56 \\
\hline & Nara & 1.11 & -1.29 & -0.18 & -1.44 & -0.28 & -0.52 & -1.24 & -2.00 & -2.07 & -0.88 \\
\hline & Niono & 1.42 & -0.89 & -0.13 & -1.02 & -0.41 & -0.16 & -0.85 & -1.59 & -1.57 & 0.58 \\
\hline & San & 1.49 & -0.68 & 0.10 & -0.78 & -0.18 & 0.00 & -0.62 & -1.35 & -1.34 & -0.40 \\
\hline & Segou & 1.37 & -0.90 & -0.11 & -1.03 & -0.34 & -0.18 & -0.81 & -1.58 & -1.53 & -0.57 \\
\hline & Senou & 1.62 & -0.51 & -0.09 & -0.61 & -0.13 & 0.15 & -0.42 & -1.17 & -1.10 & -0.25 \\
\hline & Sikasso & 1.58 & -0.39 & -0.07 & -0.44 & -0.11 & 0.22 & -0.30 & -1.01 & -0.94 & -0.16 \\
\hline & Tessalit & 1.08 & -1.34 & -0.27 & -1.48 & -0.32 & -0.56 & -1.36 & -2.09 & -2.23 & -0.95 \\
\hline \multicolumn{2}{|c|}{ Average } & 1.46 & -0.75 & -0.10 & -0.85 & -0.25 & -0.05 & -0.69 & -1.42 & -1.41 & -0.35 \\
\hline
\end{tabular}




\begin{tabular}{cccccccccccc} 
Continued & & & & & & & & \\
\hline & Bougouni & 1.71 & 0.41 & 0.27 & 0.50 & 0.45 & 0.44 & 0.38 & 0.93 & 0.86 & 0.24 \\
& Hombori & 1.83 & 0.52 & 0.36 & 0.61 & 0.60 & 0.44 & 0.54 & 1.22 & 1.18 & 0.34 \\
& Koutiala & 1.60 & 0.59 & 0.32 & 0.70 & 0.44 & 0.41 & 0.52 & 1.17 & 1.12 & 0.36 \\
& Mopti & 1.41 & 0.92 & 0.46 & 1.02 & 0.48 & 0.53 & 0.85 & 1.55 & 1.55 & 0.62 \\
& Nara & 1.37 & 1.31 & 0.59 & 1.46 & 0.49 & 0.70 & 1.25 & 2.00 & 2.07 & 0.90 \\
AME & Niono & 1.50 & 0.93 & 0.46 & 1.06 & 0.54 & 0.50 & 0.88 & 1.59 & 1.58 & 0.63 \\
& San & 1.53 & 0.75 & 0.38 & 0.85 & 0.45 & 0.47 & 0.68 & 1.35 & 1.34 & 0.48 \\
& Segou & 1.45 & 0.95 & 0.43 & 1.08 & 0.52 & 0.50 & 0.86 & 1.58 & 1.54 & 0.63 \\
& Senou & 1.65 & 0.58 & 0.31 & 0.70 & 0.47 & 0.39 & 0.52 & 1.17 & 1.10 & 0.35 \\
& Sikasso & 1.60 & 0.49 & 0.27 & 0.57 & 0.45 & 0.40 & 0.44 & 1.01 & 0.95 & 0.30 \\
& Tessalit & 1.43 & 1.34 & 0.70 & 1.49 & 0.46 & 0.64 & 1.36 & 2.09 & 2.23 & 0.95 \\
\hline Average & 1.55 & 0.80 & 0.41 & 0.91 & 0.48 & 0.49 & 0.75 & 1.42 & 1.41 & 0.53 \\
\hline
\end{tabular}

could be used as the most adapted and specific ETo for the Sudanian, Sahelian, and Saharan climate in Mali. However, with $10 \%$ of RE, it should be adjusted to the Malian climate to improve its performance using proper calibration to the local conditions.

The results of this study showed better performance of the Hargreaves and Abtew under the semiarid and arid climate in Mali than under the Western Australian semiarid climate where [24] reported RMSE of $0.94 \mathrm{~mm} /$ day, MBE of $-0.38 \mathrm{~mm} /$ day and RE of $17 \%$ for the Hargreaves equation while the Abtew equation induced $14 \%$ of relative error, RMSE of $1.014 \mathrm{~mm}$ /day and MBE of -0.4 $\mathrm{mm}$ /day. Contradictory, the Irmak's model performed well with the lowest value of MBE of $0.27 \mathrm{~mm} /$ day at Pantnagarin India among twenty ETo models [54]. The performance of Jensen-Haise equation at Tessalit is in agreement with [55] who reported large discrepancies when using this equation under extremely arid condition like the Saharan arid climate at Tessalit. Similar to the results of this study, the Jensen-Haise equation presented also the highest RMSE of 1.63 $\mathrm{mm}$ /day with a relative error over $40 \%$ in the State of Rio de Janeiro, Southeast of Brazil [56]. However, [57] reported that the Jensen-Haise equation was the best among 23 ETo methods evaluated under the extremely arid climate conditions in the central Saudi Arabia. Kingston et al. [58] reported the uncertainty of the Jensen-Haise that provided the highest estimate of ETo at $20^{\circ} \mathrm{N}$, but the lowest ETo between $50^{\circ} \mathrm{S}-60^{\circ} \mathrm{S}$ and [59] reported that Hansen equation was one of the best two performing ones with the least average monthly error in Greece. While the Hargreaves equation showed overall good performance under the semiarid and arid climates in Mali similar to the results of [60] in eastern arid and semiarid regions of Iran, it overestimated ETo under humid climate in northeast Louisiana's [37]. Jensen-Haise model showed inaccurate estimation of ETo at California wit RMSD of $4.5 \mathrm{~mm} /$ day, and $2.36 \mathrm{~mm} /$ day at Bushland (Texas) and Davis (California), respectively, [19]. Under semiarid conditions in the Southern 

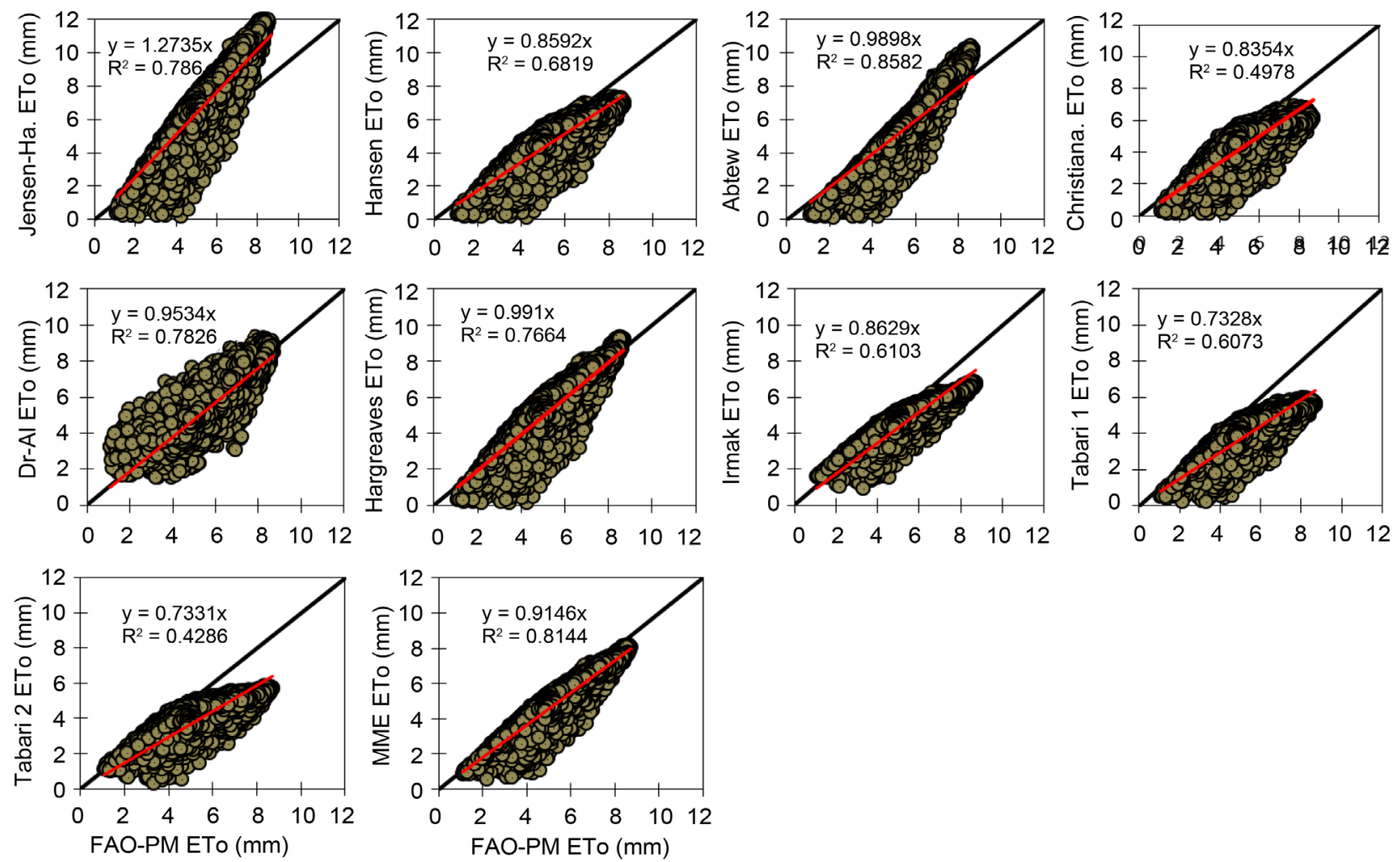

Figure 2. Relationship between the daily FAO-PM ETo estimates and the daily ETo computed by the ETo models under evaluation. 

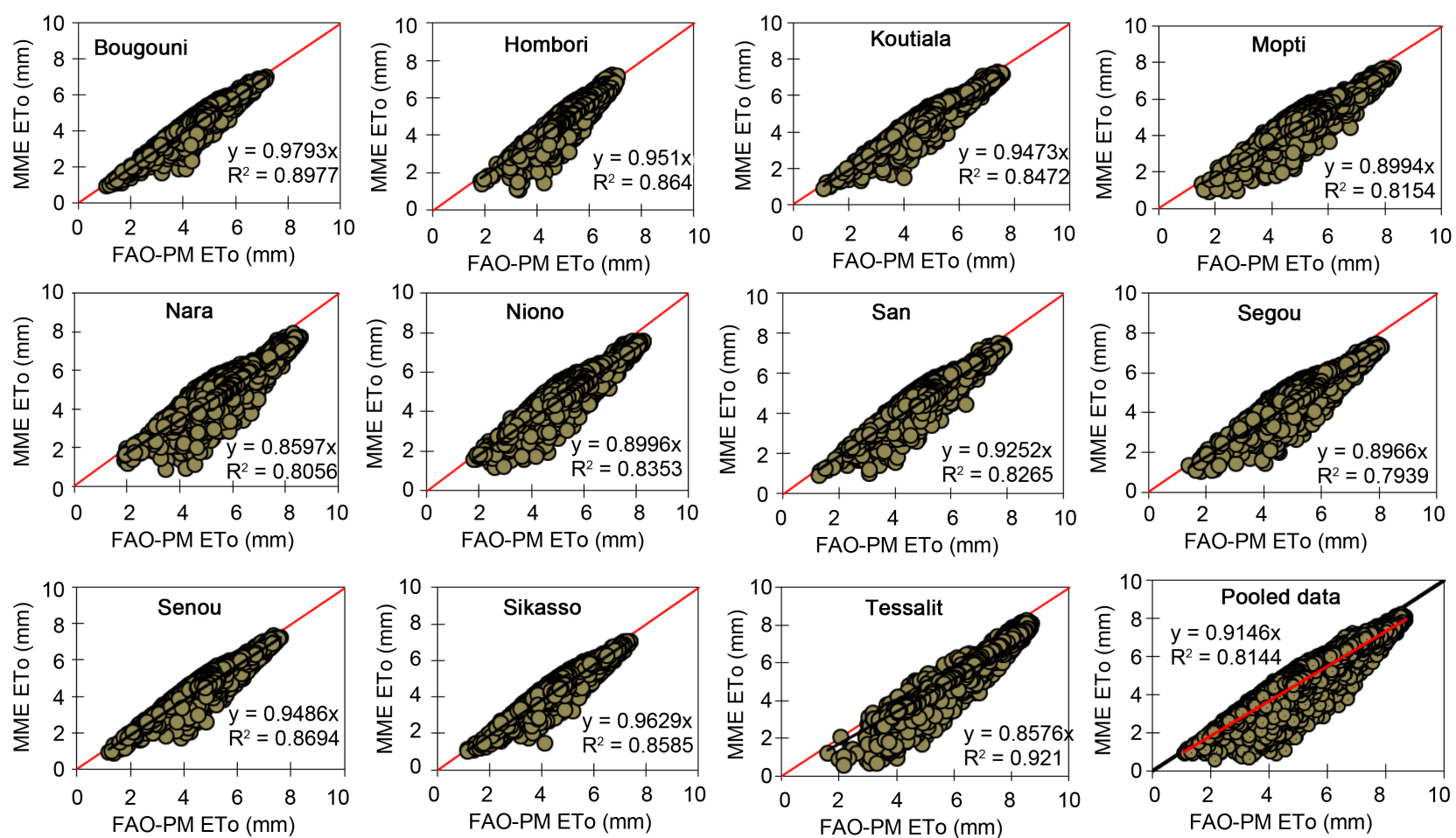

Figure 3. Relationship between the daily FAO-PM ETo estimates and the daily MME ETo estimates at all weather stations (1990-2012).

[62] and [63] who reported more than $10 \%$ reduction in model uncertainty under was achieved under MME when estimating irrigation water requirement through multi-model ensemble. Wang et al. [64] also reported the outperformance of the multiple models in a nowcast system for the monitoring of the current state of soil water.

\subsection{Calibration and Validation of the Abtew Equation}

The Abtew ETo equation was revealed the best among the selected equations with a regression slope between the FAO-PM ETo estimates and the original Abtew ETo of 0.9898 and high $\mathrm{R}^{2}$ of 0.86 (Figure 4(a)) All weather stations combined, the simple linear regression between the daily FAO-PM ETo estimates and the calibrated Abtew ETo estimates for the 1990-2003 period is presented in Figure 4(b). The regression showed the good fitness of the calibration with regression slope of 1.0035 close to unity and $\mathrm{R}^{2}=0.89$ (Figure $4(\mathrm{~b})$ ). The validation of the calibrated Abtew equation is presented in Figure 4(c). With a regression slope of almost unity (1.0288) and the $\mathrm{R}^{2}$ equal to 0.92 , the calibrated equation showed good performance and can be used for ETo estimation under the Sudanian, Sahelian, and Saharan climates in Mali. Further, the calibration process improved the RMSE of the ETo estimates from an average of 0.55 $\mathrm{mm} /$ day to $0.31 \mathrm{~mm} /$ day representing $41 \%$ improvement. The highest improvement of $63 \%$ by calibration was achieved at Tessalit while the lowest improvement of $30 \%$ was achieved at Sikasso (Table 6). The calibrated Abtew 


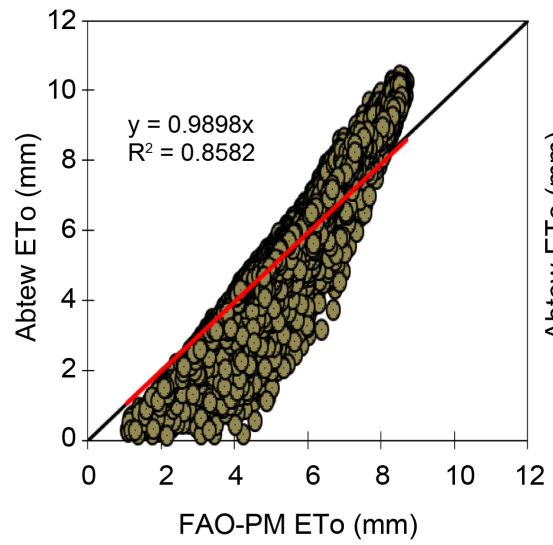

(a) Original

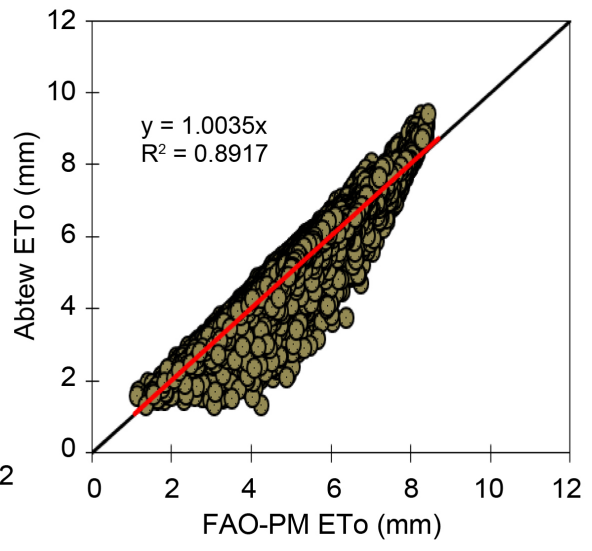

(a) Calibration

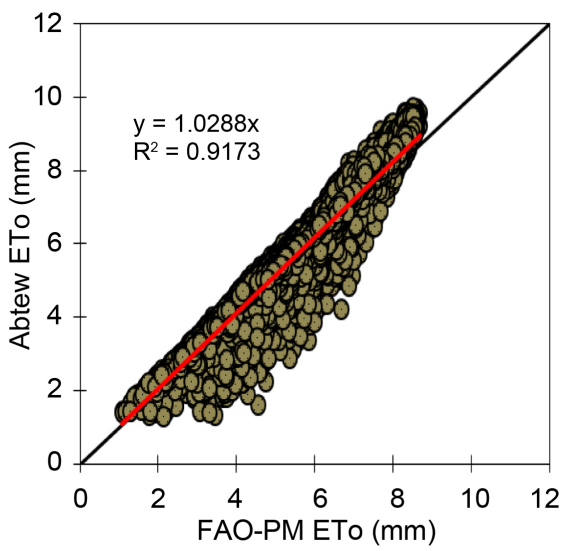

(a) Validation

Figure 4. Relationship between (a) the original Abtew ETo estimates and the FAO-PM ETo estimates for the 1990-2012 period;

(b) Calibrated Abtew ETo estimates and the FAO-PM ETo estimates for the 1990-2003.

Table 6. Improvement of the RMSE of the calibrated Abtew ETo equation.

\begin{tabular}{|c|c|c|c|}
\hline \multirow{2}{*}{$\begin{array}{l}\text { Weather } \\
\text { stations }\end{array}$} & \multicolumn{2}{|c|}{$\operatorname{RMSE}(\mathrm{mm} /$ day) } & \multirow{2}{*}{$\begin{array}{c}\text { Improvement } \\
(\%)\end{array}$} \\
\hline & Original & Calibration & \\
\hline Bougouni & 0.37 & 0.22 & 40.54 \\
\hline Hombori & 0.48 & 0.24 & 50.00 \\
\hline Koutiala & 0.44 & 0.29 & 34.63 \\
\hline Mopti & 0.60 & 0.36 & 39.59 \\
\hline Nara & 0.77 & 0.41 & 46.79 \\
\hline Niono & 0.60 & 0.35 & 41.67 \\
\hline San & 0.51 & 0.32 & 36.77 \\
\hline Segou & 0.57 & 0.39 & 31.58 \\
\hline Senou & 0.44 & 0.29 & 34.09 \\
\hline Sikasso & 0.37 & 0.26 & 29.73 \\
\hline Tessalit & 0.86 & 0.32 & 62.79 \\
\hline Average & 0.55 & 0.31 & 40.74 \\
\hline
\end{tabular}

equation performed as well during the calibration period as the validation period with the RMSE of the ETo estimated was $0.32 \mathrm{~mm} /$ day. The results of this study corroborated with the findings of [65] who reported that the Abtew model showed the best overall performance with respect to the data from all available climate stations of Central Greece, and [29] in Gansu Province, northwest China. Djaman et al. [5] reported the good fitness of the Abtew equation with FAO-PM equation under the semiarid climate in Tanzania and Kenya. Xu et al. [48] also have concluded that the simple Abtew equation can be used in the state of Vaud in Switzerland when other meteorological data except solar radiation are not available. The Calibrated Abtew equation to be used under the semiarid and arid climates in Mali climate is recommended for the study area. 


\section{Summary and Conclusion}

The FAO-PM ETo equations using missing climatic data and nine temperature reference evapotranspiration methods were evaluated for their accuracy relative to FAO-PM equation under the Sudano-Sahelo-Saharan climate across Mali for the period of 1990-2012. The results showed that under limited data conditions, the FAO-PM equation showed good performance when solar radiation (Rs), relative humidity $(\mathrm{RH})$, and wind speed (u2) are lacking solely and when both relative humidity and wind speed data are missing with RMSE varying lower than $0.58 \mathrm{~mm} /$ day and average relative error of $6.7 \%$. The Abtew ETo equation that requires solar radiation and maximum temperature showed the best performance across all three climatic zones in Mali. The Jensen-Haise equation systematically overestimated ETo while the Tabari's two equations underestimated ETo. The Irmak, Hargreaves, Hansen, Christiansen performed relatively well in the study area. With $41 \%$ improvement of the performance of the best performing Abtew equation, a new form of the Abtew equation is recommended for ETo estimation across Mali and similar climatic conditions. Also in the case of non-available $\mathrm{u} 2$ and $\mathrm{RH}$ data, the simplified forms of the FAO-PM equation is recommended for use for reasonable ETo estimation across Mali.

\section{References}

[1] Nicholson, S.E. and Grist, J.P. (2003) On the Seasonal Evolution of Atmospheric Circulation over West Africa and Equatorial Africa. Journal of Climate, 16, 1013-1030. https://doi.org/10.1175/1520-0442(2003)016<1013:TSEOTA >2.0.CO;2

[2] Allen, R.G., Pereira, L.S., Howell, T.A. and Jensen, M.E. (2011) Evapotranspiration Information Reporting: II. Recommended Documentation. Agricultural Water Management, 98, 921-929. https://doi.org/10.1016/j.agwat.2010.12.016

[3] Djaman, K., Balde, A.B., Sow, A., Muller, B., Irmak, S., Ndiaye, M.K., Manneh, B., Moukoumbi, Y.D., Futakuchi, K. and Saito, K. (2015) Evaluation of Sixteen Reference Evapotranspiration Methods under Sahelian Conditions in the Senegal River Valley. Journal of Hydrology: Regional Studies, 3, 139-159.

[4] Djaman, K., Irmak, S., Kabenge, I. and Futakuchi, K. (2016a) Evaluation of the FAO-56 Penman-Monteith Model with Limited Data and the Valiantzas Models for Estimating Reference Evapotranspiration in the Sahelian Conditions. Journal of Irrigation and Drainage Engineering, 142. https://doi.org/10.1061/(ASCE)IR.1943-4774.0001070

[5] Djaman, K., Tabari, H., Balde, A.B., Diop, L., Futakuchi, K. and Irmak S. (2016b) Analyses, Calibration and Validation of Evapotranspiration Models to Predict Grass Reference Evapotranspiration in the Senegal River Delta. Journal of Hydrology: Regional Studies, 8, 82-94.

[6] Jensen, M.E. and Haise, H.R. (1963) Estimating Evapotranspiration from Solar Radiation. Journal of the Irrigation and Drainage Division, 89, 15-41.

[7] Mendonça, J.C., Sousa, E.F., de Bernardo, S., Dias, G.P. and Grippa, S. (2003) Comparison of Estimation Methods of Reference Crop Evapotranspiration (ETo) for Northern Region of Rio de Janeiro State, Brazil. Revista Brasileira de Engenharia Agrícola e Ambiental, 7, 275-279.

https://doi.org/10.1590/S1415-43662003000200015 
[8] Trajkovic, S. and Kolakovic, S. (2009) Evaluation of Reference Evapotranspiration Equations under Humid Conditions. Water Resource Management, 23, 3057-3067. https://doi.org/10.1007/s11269-009-9423-4

[9] Thornthwaite, C.W. (1948) An Approach towards a Rational Classification of Climate. Geographical Review, 38, 55-94. https://doi.org/10.2307/210739

[10] Doorenbos, J. and Pruitt, W.O. (1977) Guidelines for Predicting Crop Water Requirements. FAO Irrigation and Drainage, Paper, 24, FAO, Rome.

[11] Hargreaves, G.H. and Samani, Z.A. (1985) Reference Crop Evapotranspiration from Temperature. Applied Engineering in Agriculture, 1, 96-99. https://doi.org/10.13031/2013.26773

[12] Allen, R.G., Pereira, L.S., Raes, D. and Smith, M. (1998) Crop Evapotranspiration: Guidelines for Computing Crop Water Requirements. FAO Irrigation and Drainage Paper No. 56, FAO, Rome.

[13] ASCE-EWRI (2005) The ASCE Standardized Reference Evapotranspiration Equation. In: Allen, R.G., Walter, I.A., Elliot, R.L., et al., Eds., Standardization of Reference Evapotranspiration Task Committee Final Report, Environmental and Water Resources Institute (EWRI) of the American Society of Civil, Engineers, ASCE, Reston, VA, 213 p.

[14] Valiantzas, J.D. (2013) Simplified Forms for the Standardized FAO-56 Penman-Monteith Reference Evapotranspiration Using Limited Data. Journal of $\mathrm{Hy}$ drology, 505, 13-23. https://doi.org/10.1016/j.jhydrol.2013.09.005

[15] Utset, A., Farre, I., Martinez-Cob, A. and Cavero, J. (2004) Comparing Penman-Monteith and Priestley-Taylor Approaches as Reference Evapotranspiration Inputs for Modeling Maize Water Use under Mediterranean Conditions. Agricultural Water Management, 66, 205-219.

https://doi.org/10.1016/j.agwat.2003.12.003

[16] López-Urrea, R., Martín de Santa, O.F., Fabeiro, C. and Moratalla, A. (2006) Testing Evapotranspiration Equations Using Lysimeter Observations in a Semiarid Climate. Agricultural Water Management, 85, 15-26. https://doi.org/10.1016/j.agwat.2006.03.014

[17] Bodner, G., Loiskandl, W. and Kaulm, H. (2007) Cover Crop Evapotranspiration under Semi-Arid Conditions Using FAO Dual Crop Coefficient Method with Water Stress Compensation. Agricultural Water Management, 93, 85-98. https://doi.org/10.1016/j.agwat.2007.06.010

[18] Xing, Z., Chow, L., Meng, F., Rees, H.W., Monteith, J. and Lionel, S. (2008) Testing Reference Evapotranspiration Estimation Methods Using Evaporation Pan and Modeling in Maritime Region of Canada. Journal of Irrigation and Drainage Engineering, 134, 417-424. https://doi.org/10.1061/(ASCE)0733-9437(2008)134:4(417)

[19] Irmak, S., Irmak, A., Howell, T.A., Martin, D.L., Payero, J.O. and Copeland, K.S. (2008) Variability Analyses of Alfalfa-Reference to Grass-Reference Evapotranspiration Ratios in Growing and Dormant Seasons. Journal of Irrigation and Drainage Engineering, 134, 147-159. https://doi.org/10.1061/(ASCE)0733-9437(2008)134:2(147)

[20] Djaman, K., Rudnick, D., Mel, V.C., Mutiibwa, D., Diop, L., Sall, M., Kabenge, I., Bodian, A., Tabari, A. and Irmak, S. (2017a) Evaluation of the Valiantzas' Simplified Forms of the FAO-56 Penman-Monteith Reference Evapotranspiration Model under Humid Climate. Journal of Irrigation and Drainage Engineering, 143.

[21] Ndiaye, P.M., Bodian, A., Diop, L. and Djaman, K. (2017) Evaluation de vingt méthodes d'estimation de l'évapotranspiration journalière de référence au Burkina 
Faso. [Evaluation of Twenty Daily Reference Evapotranspiration Estimation Methods in Burkina Faso..] Physio-Geo, 11-1, 129-146.

https://doi.org/10.4000/physio-geo.5369

[22] Djaman, K., Irmak, S. and Futakuchi, K. (2017b) Daily Reference Evapotranspiration Estimation under Limited Data in Eastern Africa. Journal of Irrigation and Drainage Engineering, 143.

[23] Tabari, H., Grismer, M. and Trajkovic, S. (2013) Comparative Analysis of 31 Reference Evapotranspiration Methods under Humid Conditions. Irrigation Science, 31, 107-117. https://doi.org/10.1007/s00271-011-0295-Z

[24] Ahooghalandari, M., Khiadani, M. and Jahromi, W.E. (2016) Calibration of Valiantzas' Reference Evapotranspiration Equations for the Pilbara Region, Western Australia. Theoretical and Applied Climatology, 128, 845-856. https://doi.org/10.1007/s00704-016-1744-7

[25] Singh, V.P. and Xu, C.Y. (1997) Evaluation and Generalization of 13 Mass-Transfer Equations for Determining Free Water Evaporation. Hydrological Processes, 11, 311-324.

https://doi.org/10.1002/(SICI)1099-1085(19970315)11:3<311::AID-HYP446>3.0.CO $\underline{; 2-\mathrm{Y}}$

[26] Tabari, H. and Hosseinzadeh-Talaee, P. (2011) Local Calibration of the Hargreaves and Priestley-Taylor Equations for Estimating Reference Evapotranspiration in Arid and Cold Climates of Iran Based on the Penman-Monteith Model. Journal of $\mathrm{Hy}$ drologic Engineering, 16, 837-845. https://doi.org/10.1061/(ASCE)HE.1943-5584.0000366

[27] Heydari, M.M. and Heydari, M. (2014) Evaluation of Pan Coefficient Equations for Estimating Reference Crop Evapotranspiration in the Arid Region. Archives of Agronomy and Soil Science, 60, 715-731. https://doi.org/10.1080/03650340.2013.830286

[28] Valipour, M. (2015) Importance of Solar Radiation, Temperature, Relative Humidity, and Wind Speed for Calculation of Reference. Archives of Agronomy and Soil Science, 6, 239-255.

[29] Zhai, L., Feng, Q., Li, Q. and Xu, C. (2010) Comparison and Modification of Equations for Calculating Evapotranspiration (ET) with Data from Gansu Province, Northwest China. Irrigation and Drainage, 59, 477-490.

https://doi.org/10.1002/ird.502

[30] Bogawski, P. and Bednorz, E. (2014) Comparison and Validation of Selected Evapotranspiration Models for Conditions in Poland (Central Europe). Water Resources Management, 28, 5021-5038. https://doi.org/10.1007/s11269-014-0787-8

[31] Thepadia, M. and Martinez, C.J. (2012) Regional Calibration of Solar Radiation and Reference Evapotranspiration Estimates with Minimal Data in Florida. Journal of Irrigation and Drainage Engineering, 138, 111-119. https://doi.org/10.1061/(ASCE)IR.1943-4774.0000394

[32] Azhar, A.H. and Perera, B.J.C. (2011) Evaluation of Reference Evapotranspiration Estimation Methods under Southeast Australian Conditions. Journal of Irrigation and Drainage Engineering, 137, 268-279. https://doi.org/10.1061/(ASCE)IR.1943-4774.0000297

[33] Abtew, W. (1996) Evapotranspiration Measurements and Modeling for Three Wetland Systems in South Florida. Journal of the American Water Resources Association, 32, 465-473. https://doi.org/10.1111/j.1752-1688.1996.tb04044.x

[34] Jabloun, M. and Sahli, A. (2008) Evaluation of FAO-56 Methodology for Estimating 
Reference Evapotranspiration Using Limited Climatic Data Application to Tunisia. Agricultural Water Management, 95, 707-715. https://doi.org/10.1016/j.agwat.2008.01.009

[35] Sentelhas, P.C., Gillespie, T.J. and Santos, E.A. (2010) Evaluation of FAO Penman-Monteith and Alternative Methods for Estimating Reference Evapotranspiration with Missing Data in Southern Ontario, Canada. Agricultural Water Management, 97, 635-644. https://doi.org/10.1016/j.agwat.2009.12.001

[36] Martinez, C.J. and Thepadia, M. (2010) Estimating Reference Evapotranspiration with Minimum Data in Florida, USA. Journal of Irrigation and Drainage Engineering, 136, 494-501. https://doi.org/10.1061/(ASCE)IR.1943-4774.0000214

[37] Rojas, J. and Sheffield, R. (2013).Evaluation of Daily Reference Evapotranspiration Methods as Compared with the ASCE-EWRI Penman-Monteith Equation Using Limited Weather Data in Northeast Louisiana. Journal of Irrigation and Drainage Engineering, 139, 285-292. https://doi.org/10.1061/(ASCE)IR.1943-4774.0000523

[38] Hansen, S. (1984) Estimation of Potential and Actual Evapotranspiration. Hydrology Research, 15, 205-212.

[39] Droogers, P. and Allen, R.G. (2002) Estimating Reference Evapotranspiration under Inaccurate Data Conditions. Irrigation Drainage System, 16, 33-45. https://doi.org/10.1023/A:1015508322413

[40] Hargreaves, G.H. and Allen, R.G. (2003) History and Evaluation of Hargreaves Evapotranspiration Equation. Journal of Irrigation and Drainage Engineering ASCE, 129, 53-63. https://doi.org/10.1061/(ASCE)0733-9437(2003)129:1(53)

[41] Irmak, S., Irmak, A., Allen, R.G. and Jones, J.W. (2003) Solar and Net Radiation-Based Equations to Estimate Reference Evapotranspiration in Humid Climates. Journal of Irrigation and Drainage Engineering, 129, 336-347. https://doi.org/10.1061/(ASCE)0733-9437(2003)129:5(336)

[42] Weigel, A.P., Liniger, M.A. and Appenzeller, C. (2008) Can Multi-Model Combination Really Enhance the Prediction Skill of Probabilistic Ensemble Forecasts? Quarterly Journal of the Royal Meteorological Society, 134, 241-260. https://doi.org/10.1002/qj.210

[43] Hagedorn, R., Doblas-Reyes, F.J. and Palmer, T.N. (2005) The Rationale behind the Success of Multi-Model Ensembles in Seasonal Forecasting. Part I: Basic Concept. Tellus, A57, 219-233.

[44] Cantelaube, P. and Terres, J. (2005) Seasonal Weather Forecasts for Crop Yield Modeling in Europe. Tellus, A57, 476-487. https://doi.org/10.3402/tellusa.v57i3.14669

[45] Guber, A.K., Pachepsky, Y.A., Van Genuchten, M.T., Rawls, W.J., Simunek, J., Jacques, D. and Cady, R.E. (2006) Field-Scale Water Flow Simulations Using Ensembles of Pedo Transfer Functions for Soil Water Retention. Vadose Zone Journal, 5, 234-247. https://doi.org/10.2136/vzj2005.0111

[46] Tebaldi, C and Knutti, R. (2007) The Use of the Multi-Model Ensemble in Probabilistic Climate Projections. Philosophical Transactions of the Royal Society A, 365, 2053-2075https://doi.org/10.1098/rsta.2007.2076

[47] Christensen, N.S. and Lettenmaier, D.P. (2007) A Multimodel Ensemble Approach to Assessment of Climate Change Impacts on the Hydrology and Water Resources of the Colorado River Basin. Hydrology and Earth System Sciences, 11, 1417-1434. https://doi.org/10.5194/hess-11-1417-2007

[48] Xu, C.Y. and Singh, V.P. (2000) Evaluation and Generalization of Radiation-Based Methods for Calculating Evaporation. Hydrological Processes, 14, 339-349. 
https://doi.org/10.1002/(SICI)1099-1085(20000215)14:2<339::AID-HYP928>3.0.CO $\underline{; 2-\mathrm{O}}$

[49] Popova, Z., Kercheva, M. and Pereira, L. (2006) Validation of the FAO Methodology for Computing ETo with Limited Data. Application to South Bulgaria. Irrigation and Drainage, 215, 201-215. https://doi.org/10.1002/ird.228

[50] Kwon, H. and Choi, M. (2011) Error Assessment of Climate Variables for FAO-56 Reference Evapotranspiration. Meteorology and Atmospheric Physics, 112, 81-90. https://doi.org/10.1007/s00703-011-0132-1

[51] Todorovic, M., Karic, B. and Pereira, L.S. (2013) Reference Evapotranspiration Estimate with Limited Weather Data across a Range of Mediterranean Climates. Journal of Hydrology, 481, 166-176. https://doi.org/10.1016/j.jhydrol.2012.12.034

[52] Wang, Y.M., Namaona, W., Gladden, L.A., Traore, S. and Deng, L.T. (2011) Comparative Study on Estimating Reference Evapotranspiration under Limited Climate Data Condition in Malawi. Int. Journal of the Physical Sciences, 6, 2239-2248.

[53] Córdova, M., Carrillo-Rojas, G., Crespo, P., Wilcox, B. and Célleri, R. (2015) Evaluation of the Penman-Monteith (FAO 56 PM) Method for Calculating Reference Evapotranspiration Using Limited Data. Application to the Wet Páramo of Southern Ecuador. Mountain Research and Development, 35, 230-239. https://doi.org/10.1659/MRD-JOURNAL-D-14-0024.1

[54] Tomar, A.S. (2015) Comparative Performance of Reference Evapotranspiration Equations at Sub-Humid Tarai Region of Uttarakhand, India. International Journal of Agricultural Research, 10, 65-73. https://doi.org/10.3923/ijar.2015.65.73

[55] Salih, A. and Sendil, U. (1984) Evapotranspiration under Extremely Arid Climates. Journal of Irrigation and Drainage Engineering, 110, 289-303. https://doi.org/10.1061/(ASCE)0733-9437(1984)110:3(289)

[56] Fernandes, L.C., Paiva, C.M. and Filho, R.C.O. (2012) Evaluation of Six Empirical Evapotranspiration Equations-Case Study: Campos dos Goytacazes/RJ. Revista Brasileira de Meteorologia, 27, 272-280. https://doi.org/10.1590/S0102-77862012000300002

[57] Al-Sha'lan, S. and Salih, A. (1987) Evapotranspiration Estimates in Extremely Arid Areas. Journal of Irrigation and Drainage Engineering, 113, 565-574. https://doi.org/10.1061/(ASCE)0733-9437(1987)113:4(565)

[58] Kingston, D.G., Todd, M.C., Taylor, R.G., Thompson, J.R. and Arnell, N.W. (2009) Uncertainty in the Estimation of Potential Evapotranspiration under Climate Change. Geophysical Research Letters, 36, L20403.

https://doi.org/10.1029/2009GL040267

[59] Xystrakis, F. and Matzarakis, A. (2011) Evaluation of 13 Empirical Reference Potential Evapotranspiration Equations on the Island of Crete in Southern Greece. Journal of Irrigation and Drainage Engineering, 137, 211-222. https://doi.org/10.1061/(ASCE)IR.1943-4774.0000283

[60] Sabziparvar, A.A. and Mirgaloybayat, R. (2015) Evaluation of Some Existing Empirical and Semi-Empirical Net Radiation Models for Estimation of Daily ET0. Journal of Advanced Agricultural Technologies, 2, 46-49. https://doi.org/10.12720/joaat.2.1.46-49

[61] Gavil'an, P., Lorite, I.J., Tornero, S. and Berengena, J. (2006) Regional Calibration of Hargreaves Equation for Estimating Reference ET in a Semiarid Environment. Agricultural Water Management, 81, 257-281. https://doi.org/10.1016/j.agwat.2005.05.001

[62] Wada, Y., Wisser, D., Eisner, S., Florke, M., Gerten, D., Haddeland, I., Hanasaki, N., 
Masaki, Y., Portmann, F.T., Stacke, T., Tessler, Z. and Schewe, J. (2013) Multi-Model Projections and Uncertainties of Irrigation Water Demand under Climate Change. Geophysical Research Letters, 40, 4626-4632.

https://doi.org/10.1002/grl.50686

[63] Multsch, S., Exbrayat, J.F., Kirk, M., Viner, N.R., Frede, H.G. and Breuer, L. (2015) Reduction of Predictive Uncertainty in Estimating Irrigation Water Requirement through Multi-Model Ensembles and Ensemble Averaging. Geoscientific Model Development, 8, 1233-1244. https://doi.org/10.5194/gmd-8-1233-2015

[64] Wang, A., Bohn, T., Mahannama, S.P., Koster, D.R. and Lettenmaier, D.P. (2009) Multimodel Ensemble Reconstruction of Drought over the Continental United States. Journal of Climate, 22, 2694-2712. https://doi.org/10.1175/2008JCLI2586.1

[65] Samaras, D.A., Reif, A. and Theodoropoulos, K. (2014) Evaluation of Radiation-Based Reference Evapotranspiration Models under Different Mediterranean Climates in Central Greece. Water Resources Manage, 28, 207-225.

https://doi.org/10.1007/s11269-013-0480-3 